\title{
PENGEMBANGAN BUKU AJAR PENDIDIKAN JASMANI DAN OLAHRAGA MELALUI PENDEKATAN SAINTIFIK KELAS IV SDN NGUTER 02 LUMAJANG
}

\author{
Trinovandhi Setyawan ${ }^{1}$ \\ Pendidikan Jasmani Kesehatan dan Rekeasi \\ Fakultas Pendidikan Ilmu Eksakta dan Keolahragaan \\ IKIP Budi Utomo Malang \\ Email: ${ }^{\text {strinovandhi@yahoo.com }}$
}

\begin{abstract}
ABSTRAK
Buku ajar merupakan buku yang diajarkan atau digunakan sebagai buku pelajaran dalam bidang studi tertentu, yang merupakan buku standar yang disusun oleh pakar dalam bidangnya, untuk maksud-maksud dan tujuan intruksional, yang dilengkapi dengan sarana-sarana pelajaran yang serasi dan mudah dipahami oleh para pemakainya disekolah-sekolah dan perguruan tinggi sehingga dapat menunjang suatu program pengajaran. Pendekatan saintifik adalah pembelajaran yang menekankan kepada suatu proses ilmiah. Pendekatan saintifik diyakini sebagai titian emas dalam perkembangan berfikir yang meliputi kemampuan psikomotor, kemampuan kognitif, dan kemampuan afektif. Langkah -langkah pembelajaran saintifik terdiri dari lima pokok pengalaman belajar seperti; (1) mengamati, (2) menanya, (3) mengumpulkan informasi, (4) mengasosiasikan dan (5) mengkomunikasikan/ menyimpulkan. Tujuan penelitian pengembangan ini adalah mengembangkan buku ajar pendidikan jasmani dan olahraga melalui pendekatan saintifik pada siswa kelas IV SD Negeri Nguter 02 Semester II Pasirian Kabupaten Lumajang pada Tahun pelajaran 2014/ 2015. Model pengembangan buku ajar ini menggunakan model pengembangan Sugiono Tahun 2010. Hasil penelitian diperoleh data sebagai berikut ; (1) Data dari Ahli pembelajaran dieproleh rata-rata 78,33\%, (2) Evaluasi untuk Ahli media di peroleh rata-rata 81,33\%, (3) Evaluasi Ahli bahasa di peroleh rata-rata 81,67\%, sedangkan untuk uji kelompok kecil ( tahap I ) diperoleh hasil 81,25\%, uji kelompok besar ( tahap II ) diperoleh rata-rata 82,72\%. Pengembangan produk buku ajar ini belum sampai pada penelitian uji efektifitas, untuk itu perlu di adakan lagi sebuah penelitian tentang efektifitas prosuk buku ajar ini yang telah dikembangkan.
\end{abstract}

Kata kunci: interaksi, teman sebaya, peserta didik

\section{ABSTRACT}

The textbook is a book taught or used as a textbook in a particular field of study, which is a standard book compiled by an expert in the field, for instructional purposes and purposes, complemented by matching learning tools and easy to understand by the wearer schools and colleges so as to support a teaching program. The scientific approach is learning that emphasizes a scientific process. The scientific approach is believed to be a golden bridge in thinking development that includes psychomotor abilities, cognitive abilities, and affective abilities. Scientific learning steps consist of five points of learning experience such as; (1) observe, (2) question, (3) gather 
information, (4) associate and (5) communicate / conclude. The purpose of this development research is to develop textbook of physical education and sports through scientific approach in fourth grade students of Nguter Second Semester II Semester II Pasirian Lumajang District in the 2014/2015 School Year. This textbook development model uses Sugiono development model in 2010. The results obtained data as follows; (1) Data from the Expert of learning dieproleh average $78.33 \%$, (2) Evaluation for media experts on average obtained $81.33 \%$, (3) Evaluation Expert language obtained an average of $81.67 \%$, while for small group test (stage I) obtained the result of $81,25 \%$, large group test (stage II) obtained average $82,72 \%$. The development of this textbook product has not reached the research of effectiveness test, for that need to be held again a study about the effectiveness of this book that has been developed.

Keywords: Development, book, teaching, approach, scientific

\section{PENDAHULUAN}

Pendidikan Jasmani dan Olahraga merupakan bagian tak terpisahkan dari pendidikan umum. Tujuannya adalah untuk membantu anak agar tumbuh dan berkembang secara wajar sesuai dengan tujuan pendidikan nasional yaitu menjadi manusia indonesia seutuhnya. Pendidikan Jasmani dan Olahraga pada hakikatnya adalah proses pendidikan yang memanfaatkan aktivitas fisik (jasmani) dan olahraga untuk menghasilkan perubahan holistik dalam kualitas individu, baik dalam hal fisik, mental serta emosional. Pendidikan jasmani dan olahraga memperlakukan anak sebagai sebuah kesatuan utuh, mahluk total, dari pada hanya menganggapnya sebagai seorang yang terpisah kualitas fisik mentalnya. Pendidikan jasmani dan Olahraga adalah bentuk pendidikan yang memberikan perhatian pada pembelajaran pengetahuan, sikap dan keterampilan gerak manusia. Pendidikan jasmani dan Olahraga mempunyai keunikan dibandingkan dengan pendidikan yang lain, yaitu yang memberikan kesempatan untuk mengembangkan karakter dan sifat sosial yang lebih besar untuk mengembangkan karakter dan sifat sosial yang lebih besar untuk diwujudkan dalam praktek pembelajaran. Pendidikan jasmani dan olahraga mempunyai unsur bermain dan olahraga, tetapi tidak semata mata hanya bermain dan olahraga saja melainkan kombinasi keduanya.

Pendidikan jasmani dan olahraga aktivitas fisik berorientasi pada tujuan pendidikan, yaitu mencoba melakukan kegiatan mendidik melalui aktivitas fisik. Akan tetapi pada kegiatan bermain dan olahraga tidak berorientasi pada tujuan pendidikan. Undang-Undang RI No.20 Tahun 2003 tentang sistem Pendidikan Nasional yang menjelaskan - 
bahwa " Pendidikan Nasional berfungsi mengembangkan kemampuan dan membentuk watak, serta peradapan bangsa, bertujuan untuk berkembangnya potensi peserta didik agar menjadi manusia yang beriman dan bertaqwa kepada Tuhan Yang Maha Esa, berakhlak mulia, sehat, berilmu dan cakap kreatif, mandiri dan menjadi warga negara yang demokratis serta bertanggung jawab." Oleh karena itu keberadaan mata pelajaran pendidikan jasmani dan olahraga kedudukannya sama dengan mata pelajaran lain dan wajib di ikuti oleh semua siswa.

Pengembangan kurikulum 2013 merupakan bagian dari strategi untuk meningkatkan kualitas pendidikan. Orientasi kurikulum 2013 adalah terjadinya peningkatan dan keseimbangan antara kompetensi sikap, keterampilan dan pengetahuan. Hal itu sejalan dengan amanat UU No. 20 Tahun 2003 sebagaimana tersurat dalam penjelasan pasal 35 , yaitu kompetensi lulusan merupakan kualitas kemampuan lulusan yang meliputi sikap, pengetahuan, dan keterampilan sesuai dengan standar nasional yang telah disepakati. Hal ini sejalan pula dengan pengembangan kurikulum berbasis kompetensi yang telah dirintis pada tahun 2004 dengan mencangkup kompetensi sikap, pengetahuan dan keterampilan secara terpadu. Perubahan kurikulum KTSP ke Kurikulum 2013 merupakan kebijakan pemerintah dalam meningkatkan kualitas pendidikan. Namun perubahan itu merupakan tantangan baru khusunya para guru. Banyak guru yang mengeluh tentang penerapan kurikulum 2013 yang dinilai terlalu cepat untuk diterapkan. Pembelajaran pendidikan jasmani dan olahraga merupakan salah satu dari mata pelajaran yang lain yang juga mengalami perubahan ke kurikulum 2013.

Mata pelajaran pendidikan jasmani dan olahraga secara umum disebutkan ada 3 konsep pendidikan yang terkait satu dengan lainnya yaitu pendidikan jasmani, pendidikan olaharga dan pendidikan kesehatan. Pendidikan jasmani adalah pendidikan lewat gerak atau permainan dan olahraga. Penjelasan di atas terdapat arti bahwa gerakan, permainan atau cabang olahraga tertentu yang dipilihnya hanyalah alat untuk mendidik. Hal ini dapat berupa keterampilan fisik dan motorik, keterampilan berfikir dan keterampilan memecahkan masalah, dan bisa juga keterampilan emosional dan sosial. Adapaun pendidikan olahraga adalah pendidikan yang membina anak agar menguasai cabang-cabang olahraga tertentu. Murid diperkenalkan berbagai cabang olahraga agar mereka menguasai keterampilan berolahraga. Selanjutnya yang ditekankan disini adalah hasil dari pembelajaran itu. Sementara yang di maksud dengan pendidikan kesehatan adalah pendidikan yang 
mengarah kepada usaha untuk membimbing atau membina kepada seseorang atau anak didik tentang kesehatan, yang meliputi seluruh aspek pribadi baik fisik, mental dan sosial agar bisa berubah dan berkembang secara harmonis. Pendidikan merupakan penerapan dari undang-undang no.20 tahun 2003 tentang Sistem Pendidikan Nasional.

Dikarenakan merupakan dasar penting untuk meningkatkanaktivitas pengembangan kemampuan jasmani anak, kompetensi dasar ini dalam pelaksanannya berpeluang besar memuncullah berbagai masalah. Upaya mengidentifikasi masalah yang dihadapi guru olahraga dalam melakukan pembelajaran jasmani adalah kesulitan memberikan pembelajaran karena dengan adanya kurikulum tematik yang bermaksud mengaitkan pembelajaran satu dengan pembelajaran lain. Penulis melakukan penelitian awal dengan melibatkan guru-guru olahraga Pendidikan Jasmani dan Olahraga sekecamatan pasirian yang tergabung dalam KKGO(Kelompok Kerja Guru Olahraga) sekecamatan pasirian sebagai sumber informasi (pengumpulan data dilakukan dengan angket, wawancara dan diskusi). Rumusan masalah dalam penelitian ini adalah bagaimana mengembangkan buku ajar pendidikan jasmani dan olahraga melalui pendekatan saintifik, agar terciptanya pembelajaran yang efektif, serta menyenangkan guna meningkatkan kinerja guru dalam membelajarkan pendidikan jasmani dan olahraga di lembaga sekolah khusunya tingkat sekolah dasar.

Pengembangan produk berupa buku ajar Pendidikan Jasmani Olahraga melaui Pendekatan Saintifik berupaya untuk menciptakan dan mengembangkan salah satu buku pembelajaran dan diharapkan buku yang dihasilkan dari penelitian ini dapat di jadikan acuan oleh guru dalam melaksanakan pembelajaran pendidikan jasmani olahraga di sekolah dasar sehingga di harapkan pula bisa meningkatkan minat belajar siswa terhadap pelajaran pendidikan jasmani olahraga. Rumusan masalah dalam penelitian ini adalah bagaimana mengembangkan buku ajar pendidikan jasmani dan olahraga melalui pendekatan saintifik, agar terciptanya pembelajaran yang efektif, serta menyenangkan guna meningkatkan kinerja guru dalam membelajarkan pendidikan jasmani dan olahraga di lembaga sekolah khusunya tingkat sekolah dasar.

Produk yang dikembangkan untuk memecahkan masalah di atas berupa pengembangan buku ajar pendidikan jasmani dan olahraga melalui pendekatan saintifik. Berikut merupakan desain spesifikasi produk : (a). Produk buku ajar pendidikan jasmani dan olahraga melalui 
pendekatan saintifik, (b). Menggunakan kertas A4 dengan berat 80 gr, (c). Buku ajar pendidikan jasmani dan olahraga melalui pendekatan saintifik disajikan dengan tampilan yang menarik. Definisi istilah adalah sebagai berikut: (a) Pendidikan Jasmani Olahraga adalah salah satu mata pelajaran yang wajib diikuti oleh anak-anak sekolah dasar yang bertujuan untuk mengembangkan keteranpilan psikomotor, kognitif dan afektif, (b) Pengembangan buku ajar pendidikan jasmani dan olahraga melalui pendekatan saintifik adalah salah satu desain yang dirancang dengan melibatkan siswa secara langsung dengan memperhatikan keaktifan siswa, kreatifitas siswa, efektifitas jalanya pembelajaran dan pembelajaran yang menyenangkan, (c) Pembelajaran melalui pendekatan saintifik adalah pembelajaran yang yang berorientasi pada kegiatan mengamati, menanya, mencoba/ mengumpulkan data, mengasosiasikan/ mengolah informasi dan mengkomunikasikan. Kurikulum SD terus berubah seiring dengan perubahan kurikulum dan jenjang pendidikan calon guru SD. Hal ini menuntut agar para calon guru SD sejak jauh hari selama proses perkuliahan terutama saat melakukan PPL akrab dengan suasana "lapangan (SD)". Saat perkuliahan dan PPL mahasiswa secara langsung harus terlibat dalam suasana pembelajaran SD.

Khusus kurikulum Pendidikan jasmani olahraga, telah mengalami perubahan nama mata pelajaran dan substansinya, mulai dengan istilah Pendidikan Jasmani, Olahraga Kesehatan, Penjaskes, Penjas, dan terakhir Pendidikan Jasmani Olahraga dan Kesehatan. Pergantian nama kurikulum pendidikan jasmani olahraga ini, berkonsekuensi kepada perubahan berbagai infrastruktur pembelajaran mulai dari penentuan tujuan, penentuan isi, proses (strategi dan pendekatan) serta evaluasinya.Namun demikian apapun istilahnya iklim belajar yang terjadi harus bersuasanakan ke SD-an. Adapun iklim belajar ke SD-an harus tercermin seperti yang ditulis Rusli Lutan (1995-1996:1-2) sebagai berikut;

Pertama, pendidikan jasmani olahraga merupakan upaya sistematis untuk pengembangan kepribadian anak, seperti pengembangan hormat diri (self esteem), kepercayaan diri, toleransi sesama kawan, dan lain-lain. Kedua, isi dari tugas ajar (learning task) diselaraskan dengan tingkat perkembangan anak. Kegiatan banyak ditandai oleh suasana kebebasan untuk menyatakan diri dan bermain secara leluasa untuk mengenal lingkungan dalam situasi yang menggembirakan.Ketiga, meskipun arah dari pengajaran, khususnya pendidikan jasmani dan olahraga juga peduli dengan pengembangan 
keterampilan suatu cabang olahraga, tetapi tekanannya lebih banyak pada pengembangan kemampuan gerak umum dan menyeluruh. Kalaupun kegiatan itu diarahkan bagi pengenalan suatu cabang olahraga, namun tugas gerak, alat dan pelaksanaannya diubah dan disesuaikan dengan kemampuan anak.Keempat, model pembelajaran lebih banyak ditandai oleh pemberian kesempatan bagi anak untuk mengekspresikan diri, berinisiatif dan memecahkan peroalan secara kreatif. Namun demikian, guru tetap memiliki peranan penting dalam mengelola proses belajar mengajar.Kelima, meskipun tujuan intruksional umum dan khusus yang menjadi sasaran belajar, tetapi diupayakan agar dampak pengiring positif yang menyangkut perkembangan penalaran dan sifat-sifat lainnya seperti disiplin, kejujuran.

Bangkitnya keinginan untuk memperbaharui kurikulum penjaskes, termasuk penerapannya, terutama didorong oleh harapan untuk meningkatkan efektivitas penjaskes itu sendiri. Apa yang diterapkan dewasa ini dilingkungan SD tidaklah sepenuhnya keliru, namun lebih condong mengarah ke upaya pengenalan dan penguasaan keterampilan suatu cabang olahraga. Pendekatan yang dipakai oleh guru-guru tak ubahnya seperti seorang melatih suatu cabang olahraga.Keadaan demikian menyebabkan hilangnya peluang "emas" untuk meraih keuntungan semaksimal mungkin dari pengajaran penjaskes sebagai medium pendidikan. Karena itu, makin kuat keyakinan dari kalangan pendidik pendidikan jasmani untuk kembali ke konsep pendidikan jasmani yang sebenarnya. Demikian pula soal penerapannya.Satu hal yang juga tidak boleh dilupakan oleh guru atau pendidik di sekolah dasar ini adalah guru hendaknya memahami karakteristik siswa yang akan di hajarkanya. Karena anak yang berada disekolah dasar masih tergolong anak usia dini, terutama dikelas awal, adalah anak yang berada pada rentangan usia dini. Masa usia dini ini merupakan masa yang pendek tetapi merupakan masa yang sangat penting bagi kehidupan seseorang. Oleh karena itu, pada masa ini seluruh potensi yang dimiliki anak perlu didorong sehingga akan berkembang secara optimal. Siswa sekolah dasar merupakan masa transisi dari sekolah taman kanak-kanak (TK) ke sekolah dasar.

Pertumbuhan dan perkembangan siswa merupakan bagian pengetahuan yang harus dimilikioleh guru. Menurut sumantri (2005:132), pentingnya mempelajari perkembangan peserta didik bagi guru, sebagai berikut :(1) Kita akan memperoleh ekspektasi yang nyata tentang anak dan remaja. (2) Pengetahuan tentang psikologi 
perkembangan anak membantu kita untuk merespon sebagaimana mestinya pada perilaku tertentu pada seorang anak. (3) Pengetahuan tentang perkembangan anak akan membantu mengenali berbagai penyimpangan dari perkembangan yang normal. (4) Dengan mempelajari perkembangan anak akan membantu memahami diri sendiri.Salah satu komponen-komponen sistem pembelajaran yang memegang peranan penting dalam pencapaian Standar Kompetensi (SK) dan Kompetensi Dasar (KD) adalah buku ajar. Menurut Suharjono (2001:24) buku ajar adalah buku yang digunakan sebagai buku pelajaran dalam bidang study tertentu, yang merupakan buku standar yang disusun oleh pakar dalam bidangnya untuk maksudmaksud dan tujuan intruksional, yang dilengkapi dengan sarana-sarana pelajaran yang serasi dan mudah dipahami oleh para pemakainya disekolah-sekolah dan perguruan tinggi sehingga dapat menunjang suatu program pengajaran.

Definisi lain menurut Mintowati (2008:54) buku ajar merupakan salah satu sarana keberhasilan proses belajar mengajar. Buku ajar merupakan suatu kesatuan unit pembelajaran yang berisi informasi, pembahasan serta evaluasi. Buku ajar yang tersusun secara sistematis akan mempermudah peserta didik dalam materi sehingga mendukung ketercapain tujuan pembelajaran. Buku ajar merupakan salah satu buku pelajaran. Buku pelajaran yang dimaksud adalah karya tulis yang digunakan guru dalam proses belajar mengajar, maka semua karya tulis termasuk buku pelajaran. Buku ajar adalah sebuah karya tulis yang berbentuk buku yang digunakan oleh guru dalam proses belajar mengajar (Lubis, 2004:17).

Berdasarkan definisi buku ajar di atas, maka disimpulkan bahwa yang dimaksud buku ajar adalah sebuah karya tulis yang bebbentuk buku dalam bidang tertentu, yang merupakan buku standar yang digunakan guru dan siswa dalam proses belajar mengajar untuk maksud-maksud tujuan intruksional, yang dilengkapi dengan saranasarana pengajaran yang serasi dan mudah dipahami oleh pemakainya disekolah-sekolah dan perguruan tinggi sehingga dapat menunjang program pengajaran.Unsur-unsur penting dalam pengertian buku ajar adalah sebagai berikut : (1) Buku ajar merupakan buku pelajaran yang ditunjukkan bagi siswa pada jenjang tertentu. (2) Buku ajar selalu berkaitan dengan mata pelajaran tertentu. (3) Buku ajar merupakan buku standar. (4) Buku aja ditulis dengan tujuan intruksional tertentu. (5) Buku ajar ditulis untuk menunjang suatu program pengajaran tertentu. (Arifin, 2009:15) 
Dengan adanya buku ajar kegiatan belajar-mengajar disekolah menjadi lebih lancar dan efektif. Dengan adanya buku ajar, keterampilan dan pengetahuan siswa telah diperoleh sebelum masuk ke kelas sehingga selama dikelas dapat dimanfaatkan untuk kegiatan pemantapan ingatan, pemahaman konsep, berfikir kritis dan pengembangan pengetahuan.Menurut Dyer (2014:53) pendekatan saintifik adalah pembelajaran melalui proses ilmiah, karena itu kurikulum 2013 mengamanatkan esensi pendekatan saintifik dalam pembelajaran. Pendekatan saintifik diyakini sebagai titian emas perkembangan dan pengembangan sikap, keterampilan, dan pengetahuan peserta didik. Dalam pendekatan atau proses kerja yang memenuhi kriteria ilmiah, para ilmuan lebih mengedepankan penalaran induktif (inductive reasoning) dibandingkan dengan penalaran deduktif (deduktif reasoning).

Penalaran deduktif melihat fenomena umum untuk kemudian menarik kesimpulan yang spesifik. Sebaliknya, penalaran induktif memandang fenomena atau situasi spesifik untuk kemudian menarik simpulan secara keseluruhan. Sejatinya, penalaran induktif menempatkan bukti-bukti spesifik kedalam relasi ide yang lebih luas. Metode ilmiah umumnya menempatkan fenomena unik dengan kajian spesifik dan detail untuk kemudian merumuskan simpulan umum. Metode ilmiah merujuk pada teknik-teknik investigasi atas suatu atau beberapa fenomena atau gejala, memperoleh pengetahuan baru, atau mengoreksi dan memadukan pengetahuan sebelumnya.

Untuk dapat disebut ilmiah, metode pencarian (method of inquiry) harus berbasis pada bukti-bukti dari objek yang dapat diobservasi, empiris, dan terukur dengan prinsip-prinsip penalaran yang spesifik. Metode ilmiah pada umumnya memuat serangkaian aktivitas pengumpulan data melalui observasi, eksperimen, mengolah informasi atau data, menganalisis, kemudian memformulasi, dan menguji hipotesis.Langkah-langkah pembelajaran dengan pendekatan ilmiah Menurut Dyer (2014:53) dan permendikbud nomor 81 A tahun 2013 lampiran IV, proses pembelajaran terdiri atas lima pengalaman belajar pokok yaitu : (a). Mengamati, (b). Menanya, (c). Mengumpulkan informasi/eksperimen, (d). Mengasosiasikan/mengolah informasi, (e). Mengkomunikasikan. 
Tabel 2.1 Langkah Pembelajaran Saintifik

\begin{tabular}{|c|c|c|}
\hline $\begin{array}{c}\text { Langkah } \\
\text { pembelajaran }\end{array}$ & Kegiatan Belajar & $\begin{array}{c}\text { Kompetensi yang } \\
\text { dikembangkan }\end{array}$ \\
\hline Mengamati & $\begin{array}{l}\text { Membaca, mendengar, menyimak, melihat } \\
\text { (tanpa atau dengan alat) }\end{array}$ & $\begin{array}{l}\text { Melatih kesungguhan, } \\
\text { ketelitian, mencari informasi }\end{array}$ \\
\hline Menanya & $\begin{array}{l}\text { Mengajukan pertanyaan tentang informasi yang } \\
\text { tidak dipahami dari apa yang diamati atau } \\
\text { pertanyaan untuk mendapatkan informasi } \\
\text { tambahan tentang apa yang diamati (dimulai } \\
\text { dari pertanyaan faktual sampai ke pertanyaan } \\
\text { yang bersifat hipotetik) }\end{array}$ & $\begin{array}{l}\text { Mengembangkan kreativitas, } \\
\text { rasa ingin tahu, kemampuan } \\
\text { merumuskan pertanyaan untuk } \\
\text { membentuk pikiran kritis yang } \\
\text { perlu untuk hidup cerdas dan } \\
\text { belajar sepanjang hayat }\end{array}$ \\
\hline $\begin{array}{l}\text { Mengumpulk } \\
\text { an informasi/ } \\
\text { eksperimen }\end{array}$ & $\begin{array}{l}\text { - melakukan eksperimen } \\
\text { - Membaca sumber lain selain buku teks } \\
\text { - Mengamati objek/ kejadian } \\
\text { - Aktivitas } \\
\text { - Wawancara dengan narasumber }\end{array}$ & $\begin{array}{l}\text { Mengembangkan sikap teliti, } \\
\text { jujur, sopan, menghargai } \\
\text { pendapat orang lain, } \\
\text { kemampuan berkomunikasi, } \\
\text { menerapkan kemampuan } \\
\text { mengumpulkan informasi } \\
\text { melalui berbagai cara yang } \\
\text { dipelajari, mengembangkan } \\
\text { kebiasaan belajar dan belajar } \\
\text { sepaniang havat. }\end{array}$ \\
\hline $\begin{array}{l}\text { Mengasosiasi } \\
\text { kan/ } \\
\text { mengolah } \\
\text { informasi }\end{array}$ & $\begin{array}{l}\text { - Mengolah informasi yang sudah } \\
\text { dikumpulkan baik terbatas dari hasil } \\
\text { kegiatan mengumpulkan/eksperimen } \\
\text { maupun hasil dari kegiatan mengamati dan } \\
\text { kegiatan mengumpulkan informasi } \\
\text { - Pengolahan informasi yang dikumpulkan } \\
\text { dari yang bersifak menambah keluasan dan } \\
\text { kedalaman sampai kepada pengolahan } \\
\text { informasi yang bersifat mencari solusi dari } \\
\text { berbagai sumber yang memiliki pendapat } \\
\text { yang berbeda sampai kepada yang } \\
\text { bertentangan. }\end{array}$ & $\begin{array}{l}\text { Mengembangkan sikap jujur, } \\
\text { teliti, disiplin, taat aturan, kerja } \\
\text { keras, kemampuan menerapkan } \\
\text { prosedur dan kemampuan } \\
\text { berpikir induktif serta deduktif } \\
\text { dalam menyimpulkan. }\end{array}$ \\
\hline $\begin{array}{l}\text { Mengkomuni } \\
\text { kasikan }\end{array}$ & $\begin{array}{l}\text { Menyampaikan hasil pengamatan, kesimpulan } \\
\text { berdasarkan hasil analisis secara lisan, tertulis, } \\
\text { atau media lainnya }\end{array}$ & $\begin{array}{l}\text { Mengembangkan sikap jujur, } \\
\text { teliti, toleransi, kemampuan } \\
\text { berpikir sistematis, } \\
\text { mengungkapkan pendapat } \\
\text { dengan singkat dan jelas, dan } \\
\text { mengembangkan kemampuan } \\
\text { berbahasa yang baik dan benar. }\end{array}$ \\
\hline
\end{tabular}


Tugas yang paling utama dalam menyelenggarakan pendidikan jasmani adalah bagaimana membantu para siswa untuk dapat menjalani proses pertumbuhan dan perkembangan secara optimal baik secara fisik, motorik, mental dan sosial. Belajar, seperti ditulis Rusli Lutan (2001:7) adalah "perubahan prilaku sebagai hasil dari pengalaman, bukan karena pengaruh faktor keturunan atau kematangan". Perubahan perilaku yang diharapkan dari belajar bersifat melekat secara permanen. Proses belajar itu sendiri tidak dapat diamati secara langsung. Namun demikian keterlaksanaannya hanya dapat ditafsirkan berdasarkan perilaku nyata yang diamati.

Perubahan-perubahan perilaku akan terjadi melalui proses mengajar yang disengaja, yang kebetulan, tidak disengaja, bahkan mungkin karena seseorang melakukan kesalahan-kesalahan belajar. Pendidikan jasmani sebagai bagian integral dan merupakan alat pendidikan banyak didefinisikan dengan berbagai macam tekanan, baik pada proses maupun tujuannya salah satunya dikutip Rusli Lutan sebagai berikut "pendidikan jasmani adalah bagian integral dari pendidikan melalui aktifitas jasmani yang bertujuan untuk meningkatkan individu secara organik, neuromuscular, intelektual, dan emosional." Pada hakekatnya ; "pendidikan jasmani adalah sebagai proses pendidikan via gerak insani (human movement) yang dapat berupa aktivitas jasmanipermainan atau olahraga untuk mencapai tujuan pendidikan” (Rusli Lutan : 7:1995-1996).

\section{METODE}

Prosedur pengembangan ini menggunakan prosedur pengembangan Sugiyono (2010:298), langkah-langkah penelitian dan pengembangan ada sepuluh langkah sebagai berikut: (1) Potensi dan masala-

(2) Pengumpulan data, (3) Desain produk, (4) Validasi desain, (5) Revisi desain, (6) Uji coba produk, (7) Revisi produk, (8) Uji coba pemakaian, (9) Revisi produk, dan produksi missal. Adapun bagan langkah-langkah penelitiannya seperti ditunjukkan pada gambar berikut: 


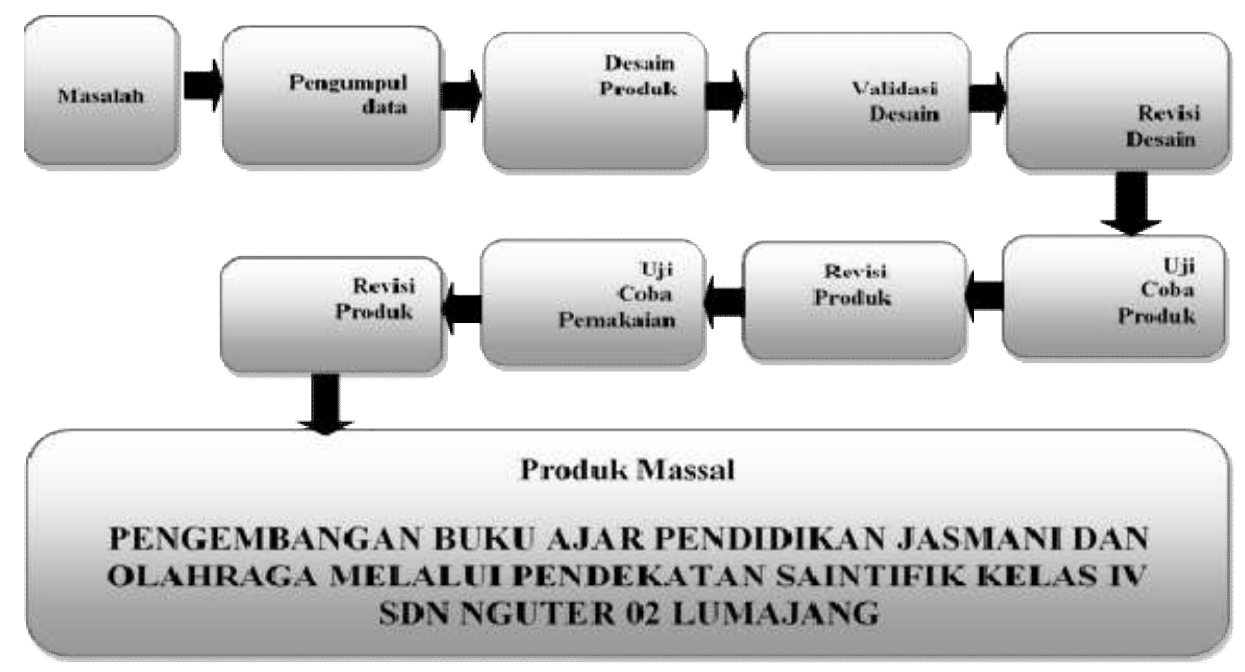

Gambar 3.1. Langkah-langkah penggunakan metode Research and Development (R\&D) menurut Sugiyono

Adapun langkah-langkah yang digunakan oleh peneliti dalam pengembangan ini adalah :(1)Potensi dan masalah diperoleh melalui analisis kebutuhan yang terdiri dari observasi, literature, wawancara, kuisioner, (2) Pengumpulan data yang terdiri dari hasil analisis kebutuhan sehingga dari data tersebut diperoleh masalah yang harus diselesaikan, (3) Desain produk meliputi pengembangan produk awal sebelum dilakukan validasi ahli, (4) Validasi desain merupakan proses setelah produk dibuat dan dilakukan validasi sebelum dilakukan uji lapangan, (5) Revisi desain untuk melakukan penyempurnaan dari masukan atas kekurangan dari hasil validasi produk, (6) Uji coba produk yang pertama pada kelompok kecil dengan sampel 5 siswa, (7)Revisi produk apabila ada hal-hal yang harus diperbaiki dari hasil uji coba kelompok kecil, (8) Uji coba pemakaian/ uji kelompok yang lebih besar 23 siswa, (9) Revisi produk adalah kegiatan akhir setelah uji kelompok besar dan merupakan uji kelompok besar yang terakhir yang menghasilkan sebuah produk jadi.

\section{Peosedur Pengembangan}

Prosedur pengembangan ini tidak memakai sepuluh langkah mengingat jumlah sekolah yang diteliti hanya satu sekolah dengan jumlah siswa yang tidak terlalu banyak, maka peneliti menyederhanakan langkah penelitian yang dilakukan. Menurut Ardhana (2002:16) bahwa setiap pengembang tentu saja dapat memilih

Trinovandhi Setyawan.Pengembangan Buku Ajar Pendidikan Jasmani dan Olahraga Melalui Pendekatan Saintifik Kelas IV SDN Nguter 02 Lumajang 
dan menentukan langkah-langkah yang paling tepat bagi dirinya berdasarkan kondisi khusus yang dihadapinya dalam proses pengembangan. Peneliti juga dapat melakukan modifikasi dari langkahlangkah yang sudah dikenalnya berdasarkan pertimbanganpertimbangan yang terbaik. Dari uraian tersebut jelas bahwa pengembang dapat menentukan langkah penelitian berdasarkan kondisi khusus yang dihadapi. Langkah yang ditempuh dalam pengembangan buku ajar ini adalah pengembangan buku ajar pendidikan jasmani dan olahraga melalui pendekatan saintifik pada siswa kelas IV SDN Nguter 02 Semester II Pasirian Kabupaten Lumajang.

\section{Peosedur Pengembangan}

Potensi masalah sangat penting sekali untuk mengetahui permasalahan dengan cara melakukan analisis kebutuhan dari pembelajaran pendidikan jasmani dan olahraga yang ada di SDN Nguter 02 Kecamatan Pasirian Kabupaten Lumajang. Analisa kebutuhan ini dilakukan dengan menggunakan angket yang diberikan kepada siswa kelas IV SDN Nguter 02 Kecamatan Pasirian Kabupaten Lumajang beserta guru pendidikan jasmani dan olahraga tersebut. Angket akan diberikan kepada siswa yang nantinya akan dianalisa sehingga kebutuhan maupun kekurangan yang ada selama ini akan diketahui. Hasil analisa kebutuhan dikonsultasikan pada dosen pembimbing sehingga akan mendapatkan jalan keluar dari masalah yang ada. Tujuan analisa kebutuhan ini untuk mengetahui permasalahan yang ada dan juga kebutuhan yang diinginkan subyek yang natinya tercipta suatu produk yang dingin dikembangkan yaitu buku ajar pendidikan jasmani dan olahraga melalui pendekatan saintifik bagi siswa kelas IV SDN Nguter 02 Kecamatan pasirian Kabupaten Lumajang.

\section{Pengumpulan Data dan Desain Produk.}

Kegiatan selanjutnya setelah analisis kebutuhan adalah mengumpulkan data-data yang nantinya dari data tersebut dibuat desain produk buku ajar pendidikan jasmani dan olahraga melalui pendekatan saintifik bagi siswa kelas IV semester genap SDN Nguter 02 Kecamatan Pasirian Kabupaten Lumajang. Produk awal pengembangan yang telah dibuat kemudian akan diujikan kepada para ahli. Beberapa ahli tersebut meliputi : Ahli pembelajaran, Ahli media dan Ahli bahasa. 


\section{Validasi Desain}

Pada tahap ketiga, desain yang sudah dibuat dilakukan validasi oleh para, ahli pembelajaran, ahli media, ahli bahasa. Hal tersebut untuk mengetahui kekurangan yang ada dengan melelui saran dan masukan disertai dengan penilaian hasil dan revisi yang akan dapat menyempurnakan hasil dari produk yang dikembangkan. Masingmasing ahli melakukan pengamatan produk yang telah dibuat dan setelah itu bentuk validasi ahli dengan cara pengisian angket dengan point-point pertanyaan yang berhubungan dengan produk tersebut baik itu meliputi isi dan juga bentuk produk.

\section{Revisi Desain}

Setelah diakukan validasi oleh para ahli maka akan didapati saran-saran yang kemudian dilakukan revisi dari saran yang telah diberikan. Hasil dari revisi produk merupakan produk pengembangan buku ajar pendidikan jasmani dan olahraga bagi siswa yang disesuaikan dengan karakteristik siswa kelas IV SDN Nguter 02 Kecamatan Pasirian Kabupaten Lumajang.

\section{Uji Coba Produk Pertama}

Setelah produk awal dilakukan revisi dari hasil validasi ahli, maka berikutnya adalah melakukan uji coba produk yang pertama. Uji coba yang yang pertama dimaksudkan untuk mengumpulkan data yang dapat digunakan sebagai dasar untuk menetapkan keefektifan, efesiensi dan daya tarik dari produk yang dihasilkan dengan draf awal berupa wawancara dan angket. Pada tahap ini uji coba dilakukan dengan menggunakan 5 siswa sebagai sampel, sebelum di ujicobakan produk ini sudah direvisi atas dasar dari hasil evaluasi ahli. Uji coba dilakukan untuk membuang kesalahan-kesalahan saat ditemui saat uji coba dan mengetahui tahapan awal produk yang dikembangkan. Prosedur yang ditempuh pada tahap ini yaitu : buku ajar pendidikan jasmani dan olahraga melalui pendekatan saintifik kelas IV SDN Nguter 02 digunakan dalam pembelajaran. Masing-masing siswa di berikan kuisioner yang berhubungan dengan buku ajar pendidikan jasmani melalui pendekatan saintifik, apabila ada kesulitan atau kekuarangan siswa dapat memberikan saran yang terdapat pada lembar saran pada bagian belakang angket. 


\section{Revisi Produk Pertama}

Revisi uji coba pertama maka akan ditemukan kekuarangan atau kesulitan yang dialami oleh siswa, maka saran dan masukan dari siswa akan dilakukan revisi produk sebelum produk di ujikan pada tahap kedua

\section{Uji Coba Pemakaian}

Dari hasil uji coba kelompok kecil dan revisi produk pertama, selanjutnya dilakukan uji coba kelompok besar. Uji coba kelompok besar dilakukan pada 23 siswa kelas IV SDN Nguter 02 Kecamatan Paisrian kabupaten Lumajang. Uji coba kelompok besar di maksudkan untuk mengetahui keefektifan produk hasil revisi sebelumnya. Prosedur yang digunakan pada tahap uji coba ini yaitu menggunkan buku ajar pendidikan jasmani dan olahraga melalui pendekatan saintifik pada siswa kelas IV SDN Nguter 02. Langkah selanjutnya meminta siswa untuk memberikan kesan dan tanggapan pada pengembangan sesuai dengan pembelajaran.

\section{Revisi Produk Akhir.}

Sebagai tindak lanjut dari uji coba pemakaian adalah revisi tahap kedua yang merupakan hasil akhir produk buku ajar pendidikan jasmani melalui pendekatan saintifik pada siswa kelas IV SDN Nguter 02 kecamatan pasirian kabupaten Lumajang.

Data yang diperoleh dari hasil evaluasi ahli, uji coba kelompok kecil dan uji coba kelompak besar berupa data kualitatif dan kuantitatif. Data kualitaif diperoleh dari hasil evaluasi berupa masukan dan saran. Sedangkan data kuantitatif dari hasil uji kelompok kecil dan kelompok besar berupa presentasi dari hasil pengumpulan dar kuisioner.Pada penelitian pengembangan buku ajar pendidikan jasmani dan olaharga melelui pendekatan saintifik untuk kelas IV SDN Nguter 02 Kecamatan Pasirian Kabupaten Lumajang, ini menggunakan instrumen pengumpulan data berupa angket yang diberikan kepada ahli pada saat melakukan validasi produk dan uji coba produk kepada siswa.

Teknik pengumpulan data dalam penelitian ini berupa angket. Angket tersebut diberikan kepada : ahli pembelajaran, ahli media, ahli bahasa dan siswa kelas IV SDN Nguter 02 Kecamatan Pasirian Kabupaten Lumajang, yang isinya dibedakan sesuai fungsi dan kebutuhan, angket untuk ahli dititik beratkan kepada produk yang dibuat. Sedangkan untuk siswa dititik beratkan dengan kesesuian dari 
produk yang dikembangkan. Setelah data diperoleh kemudian dilakukan analisis data yang setiap subyek yang meliputi evaluasi ahli media, ahli pembelajaran, ahli bahasa dan uji coba siswa, dengan pedoman sebagai berikut:

Jawaban a mempunyai nilai atau skor 1

Jawaban $\mathrm{b}$ mempunyai nilai atau skor 2

Jawaban c mempunyai nilai atau skor 3

Jawaban d mempunyai nilai atau skor 4

(Sumber: Creswell john W 2010:278)

Pengelolahan data merupakan salah satu hal yang penting dalam kegiatan penelitian pengembangan untuk mengkaji tingkat keterpakain yang diteliti. Teknik yang digunakan dalam penelitian pengembangan ini adalah teknik analisis data analisis deskriptif persentase digunakan untuk mengelolah data dari hasil penyebaran angket kepada ahli pembelajaran, ahli media, ahli bahasa dan siswa kelas IV SDN Nguter 02 Kecamatan Pasirian Kabupaten Lumajang.Analisis data kuantitatif dilakukan dengan cara ; penjelasan dari hasil pengisisan angket dan memberikan kesimpulan.

a. Rumus untuk mengolah data per subyek uji coba

$$
\begin{aligned}
& \mathrm{p}=\underline{\mathrm{X}} \times 100 \% \S \\
& \text { Keterangan : } \\
& \mathrm{p} \quad \text { : Presentase hasil evalusai } \\
& \mathrm{X} \quad \text { : Jumlah jawaban skor oleh subyek uji coba } \\
& \mathrm{Xi} \quad \text { : Jumlah jawaban maksimal dalam aspek penilaian oleh } \\
& \text { subyek uji coba. } \\
& 100 \% \text { : Kostanta }
\end{aligned}
$$

b. Rumus untuk mengolah data secara keseluruhan subyek uji coba.

$$
\mathrm{p}=\frac{\sum \mathrm{X}}{\sum \mathrm{X} 1} \times 100 \%
$$

Keterangan :

$\mathrm{p} \quad$ : Presentase hasil keseluruhan evaluasi subyek uji coba

$\sum X$ : jumlah keseluruhan jawaban subyek uji coba dalam keseluruhan aspek penilaian

$\sum X$ : Jumlah keseluruhan skor maksimal subyek uji coba dalam keseluruhan aspek penilaian.

$100 \%$ : konstanta 
Untuk menentukan kesimpulan yang telah didapat, maka ditetapkan criteria persentase sebagai beikut :

Untuk menentukan kesimpulan yang telah didapat, maka ditetapkan criteria persentase sebagai beikut :

Tabel 3.1 Analisis Persentase

\begin{tabular}{c|r}
\hline Persentase & \multicolumn{1}{|c}{ Keterangan } \\
\hline $80 \%-100 \%$ & Valid \\
\hline $60 \%-79 \%$ & Cukup valid \\
\hline $50 \%-69 \%$ & Tidak valid/ diganti \\
\hline$<\mathbf{5 0} \%$ & \\
\hline
\end{tabular}

Sumber. Sudjana (1990:45)

\section{HASIL DAN PEMBAHASAN}

Hasil pengembangan akan menyajikan data tentang (1) analisis kebutuhan, (2) ahli pembelajaran, (3) ahli media, (3) ahli bahasa, (4) siswa kelas IV SDN Nguter 02 Kecamatan Pasirian Kabupaten Luamajang.Peneliti untuk mendapatkan data uji coba tahap I dan tahap II pengembangan buku ajar pendidikan jasmani dan olahraga melalui pendekatan saintifik pada siswa kelas IV SDN Nguter 02 Kecamatan Pasirian Kabupaten Lumajang, peneliti menggunakan instrumen dalam bentuk angket ditunjukkan pada 3 ahli yaitu: ahli pembelajaran, ahli media, ahli bahasa. Untuk uji coba lapangan dilaksanakan sebanyak dua kali yakni uji coba kelompok kecil sebanyak 5 orang, dan uji kelompok besar 23 orang. Tabel 4.1 berikut akan menyajikan data hasil analisis kebutuhan, data evaluasi dari ahli pembelajaran, ahli media, ahli bahasa, uji coba tahap I (kelompok kecil) maupun uji coba tahap II (kelompok besar).Hari bermain dengan teman-teman termasuk dalam kategori sangat baik meskipun rata-rata item ini sebesar 3,3. 
Tabel 4.1 Data Hasil Analisis Kebutuhan, Evaluasi Ahli, Uji coba Tahap I (Kelompok Kecil) dan Uji Coba Tahap II (Kelompok Besar)

\begin{tabular}{|c|c|c|}
\hline No & Komponen & Temuan \\
\hline \multirow[t]{2}{*}{1.} & $\begin{array}{l}\text { a. Analisis } \\
\text { Hasil obutuhan } \\
\text { dilapangan dengan } \\
\text { guru pendidikan } \\
\text { jasmani oleharaga } \\
\text { dan } \quad \text { kesehatan } \\
\text { melalui angket }\end{array}$ & $\begin{array}{l}\text { a. Siswa SDN Nguter } 02 \text { kecamatan pasirian kabupaten } \\
\text { lumajang masih menggunakan kurikulum KTSP } \\
\text { (Kurikulum Tingkat Satuan Pendidikan) } \\
\text { b. Belum adanya pembelajaran pendidikan jasmani dan } \\
\text { olaharga mellaui pendekatan saintifik. } \\
\text { c. Pembelajaran bersifat konveksional dan monoton. } \\
\text { d. Perlu dikembangakan pembelajaran yang baru dan } \\
\text { menyenangkan. }\end{array}$ \\
\hline & $\begin{array}{l}\text { b. Hasil observasi } \\
\text { dilapangan dengan } \\
\text { pembelajaran } \\
\text { pendidikan jasmani } \\
\text { dan olahraga di SD } \\
\text { Negeri Nguter 02 } \\
\text { Pasirian Kabupaten } \\
\text { Lumajang melalui } \\
\text { angket yang } \\
\text { diberikan kepada } \\
\text { siswa. } \\
\end{array}$ & $\begin{array}{l}\text { a. Siswa kurang tertarik belum memberikan pembelajaran } \\
\text { pendiidkan jasmani dan olaharga melalui pendekatan } \\
\text { saintifik dengan persentase } 73,33 \% \text {. } \\
\text { b. Siswa sangat setuju dengan diberikan pembelajaran } \\
\text { pendidikan jasmani dan olahraga melalui pendekatan } \\
\text { saintifik dengan persentase } 81,46 \%\end{array}$ \\
\hline No & Komponen & Temuan \\
\hline 2 . & $\begin{array}{l}\text { Evaluasi Ahli } \\
\text { Pembelajaran Hasil } \\
\text { evaluasi ahli } \\
\text { pembelajaran }(\mathrm{n}=1) \\
\text { dengan jumlah } \\
\text { intrumen sebanyak } \\
15 \text { pertanyaan. }\end{array}$ & $\begin{array}{l}\text { a. Dari evaluasi ahli pembelajaran diperoleh hasil } 78,33 \% \\
\text { pengembangan buku ajar pendidikan jasmani dan olahraga } \\
\text { melalui pendekatan saintifik memang perlu untuk } \\
\text { dilaksanakan. } \\
\text { b. Masukan dan saran yang diperoleh dari ahli pembelajaran } \\
\text { adalah lebih banyak lagi gambar untuk teknik dasar lainnya. }\end{array}$ \\
\hline & $\begin{array}{l}\text { b. Evaluasi ahli media } \\
\text { Hasil evaluasi ahli } \\
\text { media (n = } 1) \\
\begin{array}{ll}\text { sebanyak } & 15 \\
\text { pertanyaan }\end{array}\end{array}$ & $\begin{array}{l}\text { a. Dari evaluasi ahli media di peroleh hasil sebesar } 83,33 \% \\
\text { sehingga buku ajar pendidikan jasmani dan olaharga } \\
\text { melalui pendekatan saintifik dapat digunakan. } \\
\text { b. Masukan dan saran yang diperoleh dari ahli media adalah } \\
\text { (1) cover sebaiknya di tambah dan disesuaikan dengan } \\
\text { sekolah, (2) penggunaan gambar akan lebih menarik } \\
\text { apabila ada gambar teknik dasar apada setiap materi. } \\
\end{array}$ \\
\hline & $\begin{array}{l}\text { c. Evaluasi ahli bahasa. } \\
\text { Hasil evaluasi ahli } \\
\text { bahasa (n }=1) \\
\begin{array}{l}\text { sebanyak } \\
\text { pertanyaan. }\end{array}\end{array}$ & $\begin{array}{l}\text { a. Dari evaluasi ahli bahasa diperoleh sebesar } 81,67 \% \\
\text { sehingga bahasa yang digunakan dalam penulisan ini dapat } \\
\text { digunakan. } \\
\text { b. Masukan dan saran yang diperoleh dari ahli bahasa adalah } \\
\text { (1) sedikit ada huruf yang ukuranya tidak standart, (2) } \\
\text { penggunaan tulisan dan bahasa lebih baiknya ada warna } \\
\text { setiap bab. }\end{array}$ \\
\hline
\end{tabular}




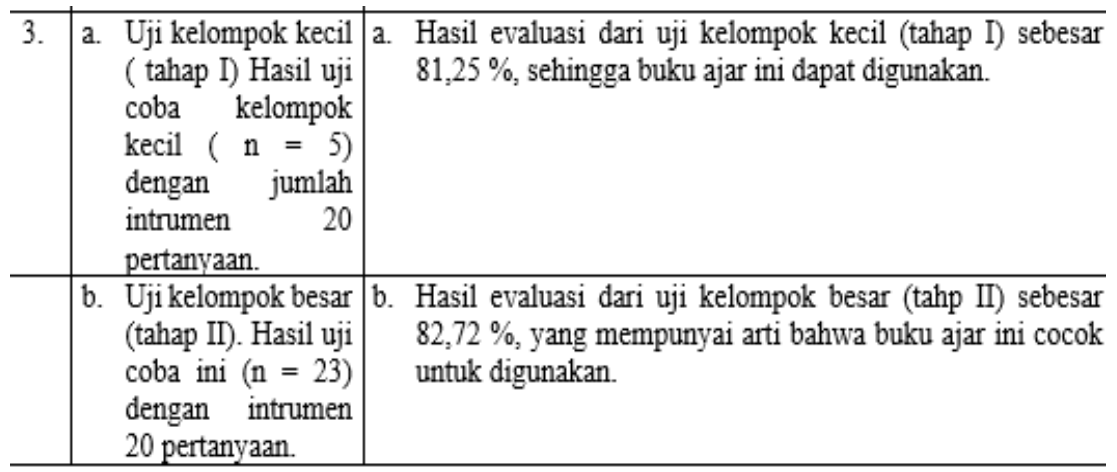

\section{Ahli Pembelajaran}

Evaluasi ahli pembelajaran dilakukan oleh Yuni Irwanto, M.Pd, yang bersangkutan memiliki kriteria sebagai berikut : (1) Dosen IKIP Budi Utomo Malang dan Guru pendidikan jasmani dan olahraga di SDN sememu 01 pasirian kabupaten lumajang. Paparan data hasil evaluasi ahli disajikan pada table 4.2.

Tabel 4.2 menyajikan data dari evaluasi ahli pembelajaran terhadap rancangan pengembangan buku ajar pendidikan jasmani dan olahraga melalui pendekatan saintifik dengan pedoman sebagai berikut : (1) nilai 4 apabila jawaban sangat cocok, sangat jelas, sangat sesuai, sangat menyenangkan, dan sangat mudah; (2) nilai 3 apabila jawaban cocok, jelas, sesuai, menyenangkan, dan mudah ; (3) nilai 2 apabila jawaban kurang cocok, kurang jelas, kurang sesuai, kurang menyenangkan, sulit ; (1) nilai 1 apabila jawaban tidak cocok, tidak jelas, tidak sesuai, tidak menyenangkan dan sangat sulit.

Tabel 4.2 Data Hasil Evaluasi Ahli Pembelajaran dan intrumen 15

\begin{tabular}{|c|c|c|c|c|c|}
\hline & \multicolumn{5}{|c|}{ pertanyaan. } \\
\hline No. & Ahli & $\begin{array}{c}\text { Skor } \\
\text { Minimal }\end{array}$ & $\begin{array}{c}\text { Skor } \\
\text { Maksimal }\end{array}$ & $\begin{array}{c}\text { Skor } \\
\text { Hasil }\end{array}$ & Persentase \\
\hline 1. & $\begin{array}{l}\text { Ahli } \\
\text { Pembelajaran }\end{array}$ & 15 & 60 & 47 & 78,33 \\
\hline
\end{tabular}




\section{Ahli Media}

Evaluasi ahli media dilakukan oleh (1) Tria Muhamad Aris, M. Pd., sebagai Dosen IKIP Budi Utomo Malang tersebut disajikan pada table 4.3. berikut ini menyajikan data ahli media terhadap rancangan buku ajar pendidikan jasmani dan olahraga melalui pendekatan saintifik dengan pedoman sebagai berikut : (1) nilai 4 apabila jawaban sangat cocok, sangat jelas, sangat sesuai, sangat menyenangkan, dan sangat mudah; (2) nilai 3 apabila jawaban cocok, jelas, sesuai, menyenangkan, dan mudah ; (3) nilai 2 apabila jawaban kurang cocok, kurang jelas, kurang sesuai, kurang menyenangkan, sulit ; (1) nilai 1 apabila jawaban tidak cocok, tidak jelas, tidak sesuai, tidak menyenangkan dan sangat sulit.

Tabel 4.3 Data Hasil Evaluasi Ahli Media dengan intrumen sebanyak 15 pertanyaan.

\begin{tabular}{cccccc}
\hline No. & Ahli & $\begin{array}{c}\text { Skor } \\
\text { Minimal }\end{array}$ & $\begin{array}{c}\text { Skor } \\
\text { Maksimal }\end{array}$ & $\begin{array}{c}\text { Skor } \\
\text { Hasil }\end{array}$ & Persentase \\
\hline 1. & Ahli & 15 & 60 & 50 & 83,33 \\
\hline
\end{tabular}

\section{Ahli Bahasa}

Evaluasi ahli bahasa dilakukan oleh (1) Priyo Santoso, M.Pd., sebagai Dosen STIH Lumajang dan Guru SMP Negeri 03 Pasirian Kabupaten Luamjang tersebut disajikan pada table 4.4. berikut ini menyajikan data ahli bahasa terhadap rancangan buku ajar pendidikan jasmani dan olahraga melalui pendekatan saintifik dengan pedoman sebagai berikut : (1) nilai 4 apabila jawaban sangat cocok, sangat jelas, sangat sesuai, sangat menyenangkan, dan sangat mudah; (2) nilai 3 apabila jawaban cocok, jelas, sesuai, menyenangkan, dan mudah ; (3) nilai 2 apabila jawaban kurang cocok, kurang jelas, kurang sesuai, kurang menyenangkan, sulit ; (1) nilai 1 apabila jawaban tidak cocok, tidak jelas, tidak sesuai, tidak menyenangkan dan sangat sulit.

Tabel 4.4 Data Hasil Evaluasi Ahli Bahasa dengan intrumen sebanyak 15 pertanyaan.

\begin{tabular}{lcc|c|c|c}
\hline No. & Ahli & $\begin{array}{c}\text { Skor } \\
\text { Minimal }\end{array}$ & $\begin{array}{c}\text { Skor } \\
\text { Maksimal }\end{array}$ & $\begin{array}{c}\text { Skor } \\
\text { Hasil }\end{array}$ & Persentase \\
\cline { 3 - 6 } & Ahli & 15 & 60 & 49 & 81,67 \\
\hline
\end{tabular}




\section{Pengelolahan Data Keseluruhan Hasil Uji Coba Kelompok Kecil (Tahap I)}

Uji coba kelompok kecil dilakukan pada siswa kelas IV sejumlah 5 siswa yang diperoleh hasil seperti yang disajikan pada table 4.5.Tabel 4.5 berikut ini menyajikan data hasil uji coba kelompok kecil terhadap rancangan buku ajar pendidikan jasmani dan olahraga melalui pendekatan saintifik dengan pedoman sebagai berikut; (1) nilai 4 apabila jawaban sangat cocok, sangat jelas, sangat sesuai, sangat menyenangkan, dan sangat mudah; (2) nilai 3 apabila jawaban cocok, jelas, sesuai, menyenangkan, dan mudah ; (3) nilai 2 apabila jawaban kurang cocok, kurang jelas, kurang sesuai, kurang menyenangkan, sulit; (1) nilai 1 apabila jawaban tidak cocok, tidak jelas, tidak sesuai, tidak menyenangkan dan sangat sulit. ini sebesar 2,5.

Tabel 4.5 Data Hasil Keseluruhan Hasil Uji Coba Kelompok Kecil (Tahap I) Dengan Intrumen 20 Pertanyaan

\begin{tabular}{c|c|c|c|c|c}
\hline No. & Komponen & $\begin{array}{c}\text { Skor } \\
\text { Minimal }\end{array}$ & $\begin{array}{c}\text { Skor } \\
\text { Maksimal }\end{array}$ & $\begin{array}{c}\text { Skor } \\
\text { Hasil }\end{array}$ & Persentase \\
\hline 1. & $\begin{array}{c}\text { UjiCobaKelompok } \\
\text { Kecil (Tahap I) }\end{array}$ & 100 & 400 & 325 & 81,25 \\
\hline
\end{tabular}

\section{Pengelolahan Data Keseluruhan Hasil Uji Coba Kelompok Kecil (Tahap I)}

Uji coba kelompok besar dilakukan pada siswa kelas IV sejumlah 23 siswa yang diperoleh hasil seperti yang disajikan pada table 4.6. Tabel 4.6 berikut ini menyajikan data hasil uji coba kelompok besar terhadap rancangan buku ajar pendidikan jasmani dan olahraga melalui pendekatan saintifik dengan pedoman sebagai berikut; (1) nilai 4 apabila jawaban sangat cocok, sangat jelas, sangat sesuai, sangat menyenangkan, dan sangat mudah; (2) nilai 3 apabila jawaban cocok, jelas, sesuai, menyenangkan, dan mudah ; (3) nilai 2 apabila jawaban kurang cocok, kurang jelas, kurang sesuai, kurang menyenangkan, sulit ; (1) nilai 1 apabila jawaban tidak cocok, tidak jelas, tidak sesuai, tidak menyenangkan dan sangat sulit. 
Tabel 4.6 Data Hasil Keseluruhan Hasil Uji Coba Kelompok Besar (Tahap II) Dengan Instrumen 20 Pertanyaan.

\begin{tabular}{c|c|c|c|c|c}
\hline No & Komponen & $\begin{array}{c}\text { Skor } \\
\text { Minimal }\end{array}$ & $\begin{array}{c}\text { Skor } \\
\text { Maksimal }\end{array}$ & $\begin{array}{c}\text { Skor } \\
\text { Hasil }\end{array}$ & Prsentase \\
\hline 1. & $\begin{array}{c}\text { UjiCobaKelompok } \\
\text { Besar (Tahap II) }\end{array}$ & 460 & 1840 & 1522 & 82,72 \\
\hline
\end{tabular}

Berdasarkan sajian data, pada bagian ini akan di uraikan analisis data yang diperoleh dari ahli pembelajaran, ahli media, ahli bahasa dan pada siswa kelas IV SD Negeri Nguter 02 pada uji coba kelompok kecil (tahap I) dan uji kelompok besar (tahap II).

\section{SIMPULAN}

Berdasarkan hasil penelitian yang dilakukan, maka produk dalam bentuk buku yang dikembangkan perlu di kaji ulang keberadaanya, karena setelah melalui proses penelitian terdapat beberapa hal yang perlu diperbaiki. Produk yang dikembangkan ini adalah Buku ajar pendidikan jasmani dan olahraga melalui pendekatan saintifik untuk siswa kelas IV SD Negeri Nguter 02 Pasirian Kabupaten Lumajang.Berdasarkan data dari tinjauan ahli pembelajaran, ahli media, ahli bahasa dan uji coba lapangan dan pengamatan peneliti selama pengembangan dilakukan, terdapat beberapa revisi terhadap produk buku yang dikembangkan, di antaranya adalah: (a). Aspek ketepatan tulisan, kemenarikan gambar cover, dan ketepatan perpaduan warna cover, serta bahasa yang kurang menarik dalam buku ajar pendidikan jasmani dan olahraga melalui pendekatan saintifik pada siswa kelas IV SD Negeri Nguter 02 Pasirian Kabupaten Lumajang, (b). Saran atau masukan dari ahli pembelajaran, ahli media dan ahli bahasa adalah memperbanyak gambar tampilan teknik dasar setiap bab, memperbaiki tulisan serta tampilan cover lebih menarik agar lebih sempurna.

Dalam mengembangkan penelitian ini kearah lebih lanjut, peneliti mempunyai saran sebagai berikut: (a). Memperluas subyek penelitian, baik itu untuk siswa maupun untuk sekolah yang digunakan untuk uji coba, (b). Lebih banyak literatur, baik itu untuk ahli pembelajaran, ahli media dan ahli bahasa, (c). Hasil dari penelitian ini hanyalah sebuah pengembangan produk buku ajar dan belum sampai pada penelitian uji efektifitas, untuk itu perlu di adakan lagi sebuah penelitian tentang efektifitas produk yang telah dikembangkan tersebut. 


\section{DAFTAR PUSTAKA}

Alamudi, Aam, dkk. 2009. Statistika Dasar. Bogor: Grasindo.

Alwi. 2005. Kamus Besar Bahasa Indonesia. Jakarta: Pusat Bahasa.

Arief, S. Sadiman, dkk. 2002. Media Pendidikan, Pengembangan dan pemanfaatan. Jakarta : Raja Grafindo Persada.

Arikunto, Suharsimi. 2006. Prosedur Penelitian Suatu Pendekatan Praktik. Jakarta: Rineka Cipta.

Borg, W. R. \& Gall, M. D. Gall. (1989). Educational Reasearch: An Introduction, Fifth Edition. New York: Logman.

BNSP. 2006. Standart Isi Sekolah Dasar Negeri. Jakarta: Badan Standart Nasional Pendidikan.

Dimyati \& Mudjiono. 2009. Belajar dan Pembelajaran. Jakarta: Rineka Cipta.

Daryanto. 2014. Pembelajaran Tematik Terpadu Terintegrasi Kurikulum 2013. Malang: Gava Media.

Fathurrohman, Pupuh \& Sutikno, M. Sobry. 2010. Strategi Belajar Mengajar. Bandung: Refika Aditama.

Giriwijoyo, Santoso \& Sidik, Zafar, Dikdik. 2012. Ilmu Faal Olahraga (Fisiologi Olahraga). Bandung: Rosda.

Giriwijoyo, Santoso \& Sidik, Zafar, Dikdik. 2012. Ilmu Kesehatan Olahraga. Bandung: Rosda.

Jauhari, Ahmad. 2013. Dasar-Dasar Ilmu Gizi. Yogyakarta: Jaya Ilmu. Komarudin. 2013. Psikologi Olahraga. Bandung: Rosda.

Majid, Abdul. 2014. Pembelajaran Tematik Terpadu. Bnadung: Rosda.

Moleong, Lexy J. 2004. Metodologi Penelitian Kualitatif. Columbus, Chio, USA: Rosda.

Patururi, Achmad. 2012. Manajemen Pendidikan Jasmani Dan Olahraga. Jakarta: 2012.

Purwadi, Mardiana \& Indra, Wira. 2008. Pendidikan Jasmani dan Olahraga. Jakarta: Universitas Terbuka.

Rosdidi, Sakban. 2014. Penelitian Terapan Profesi Pendidikan. Malang: Nams.

Rusman. 2012. Model-Model Pembelajaran. Bandung: Raja Persindo Persada.

Sani, Abdullah. 2014. Pembelajaran Saintifik Untuk Implementasi Kurikulum 2013. Jakarta: Bumi Aksara.

Shoimin, Aris. 2014. 68 Model Pembelajaran Inovatif Dalam Kurikulum 2013. Rembang: AR-Ruzz Media.

Sisik, Zafar, Dikdik. 2010. Mengajar Dan Melatih Atletik. Bandung: Rosda. 
Subarja, Herman. 2007. Permainan Kecil Di Sekolah Dasar. Jakarta: Universitas Terbuka.

Susanto, Ahmad. 2015. Teori Belajar Pembelajaran Di Sekolah Dasar. Jakarta: Predanamedia Group. 